\title{
CONSCIOUS PARENTING IN UKRAINE AND FINLAND
}

\author{
Victoria Vorozhbit-Horbatyuk \\ Skovoroda Kharkiv National Pedagogical University, Ukraine \\ Yana Volkova \\ Skovoroda Kharkiv National Pedagogical University, Ukraine \\ Maryna Stefan \\ Skovoroda Kharkiv National Pedagogical University, Ukraine
}

\begin{abstract}
The current state of upbringing is characterised by a blurring of methodological foundations for understanding the spiritual basis of upbringing of a personality, and an exaggeration of the role of the rational component in this process. We can trace the lack of attention to the social nature of upbringing. The process of upbringing is often excessively individualised and isolated by the framework of a particular person, real living conditions, etc. Such an approach complicates social interaction at the level of personal communication and impedes the integrity of educational influences. The formation of conscious parenthood as a basic value of a civilised society can help to achieve this.

A pedagogical retrospection on the valuable pedagogical experience of the past is chosen as one of the information blocks. The idea of developing moral feelings, will and responsibility is revealed through the traditions of Ukrainian folk pedagogy, pedagogical analysis of traditional rituals that accompany the stages of human maturation and are preserved in our time.

It is important for Ukraine and Finland to realise that the ideal of education is created in the family circle and its basic values are inner spirituality, ethical responsibility, versatile education, open-mindedness, effective desire for the good of the Motherland, honesty, mercy, charity, gentleness, politeness, restraint, courage and patience in the hardships of life.

As a promising direction for developing the issue of conscious fatherhood, we see the creation of opportunities for sharing experiences, forming family and community education traditions, sharing experiences of constructive cooperation between teachers and parents with teambuilding resources in the implementation of an individual child success programme.
\end{abstract}

Keywords: child, cultural visibility, fatherhood, parenting, pedagogical retrospection, social interaction.

\section{Introduction}

Problem statement. The European scientific and educational community has a decisive mission: to contribute to the preservation of peace and harmony in society. The production of strict quarantine measures in 2020, the activation of 
distant formats of interaction between participants in the educational process all over the world have shown that the most valuable thing in a person's growth is his or her immediate family and friendship circle.

The importance of parenting or parenthood in relation to a child cannot be overemphasised. With the implementation of quarantine measures in 2019-2021. The level of development of collective life in children's social groups has decreased considerably, with the vast majority of forms of collective interaction moving to virtual activities and games activities.Therefore, in our opinion, the process of qualitative renewal of cooperation between teachers, educators and parents / persons implementing the functions of parenthood in relation to the child is in demand. Based on the peculiarities of the present educational transformation, the aim of this article is to analyse the phenomenon of conscious fatherhood in Ukraine and Finland. We have noted that the current upbringing of personality is characterised by the vagueness of the value basis of education, exaggeration of the importance of the rational component, when all educational efforts are aimed at the development of life competences. The spiritual basis of growing up has been neglected. We have carried out a retrospective reconnaissance and tried to draw relevant pedagogical parallels, which prove: it is important to prioritise the social nature of upbringing. In the context of progressing ideas of corporatism, excessive individualisation and specificity of child upbringing harms the integrity of this process. Strict adherence to the real living conditions and regional component in the organisation of education in the content of a certain degree contradicts the mobility and openness of modern man, educational processes. We argue for the expediency of conscious parenthood as a basic value of civilised society, using the logical links of the historical experience of Ukraine and Finland as an example.

Purpose of the study: to reveal the historical formation of conscious parenthood as a basic value of civilised society, using the experience of teachers in Ukraine and Finland as an example.

The value-based and attitudinal nature of the research subject determined the choice of research methods: analysis of applied principles of child education in Ukraine and Finland, moral and scientific-pedagogical argumentation of the content, forms and methods of cooperation between teachers and parents, dissemination of actual experience in the new conditions of intercultural interaction of Ukrainian and Finnish educators.

\section{Theoretical Framework}

For many current theories of parenting conscious parenting is a basic concept. For example: anthropological upbringing of labour education in K. Ushinskiy (1990), upbringing of a sense of security in the collective by 
A. Makarenko (1973), education of individuality by Sukhomlynskyi (1977), development of mental powers of the child by Lokk (2020), J. Pestalotstsy (2009), nature-appropriate education by G. Skovoroda (Skovoroda, 2006), civic education by H. Vashchenko (1994). Behaviourism, cognitivism and constructivism provide the psychological underpinnings of the concept of conscious fatherhood. Behaviourism, for example, helps to establish rules during the educational process and manage the group based on Pavlov's (1954) doctrine of two signalling systems and involves repetitive actions, verbal reinforcement and incentives to participate.

Cognitivism gained progression in the early 1900s in Germany on the basis of Wolfgang Köhler's Gestalt psychology (Keler, 1998). In the theory of cognitivism, education involves the learner reorganising information, seeking new explanations and adapting old ones. This transformation of knowledge is accompanied by a change in behaviour according to Z. Piazhe (2008).

Constructivism is based on the assertion that we construct new ideas on the basis of previous knowledge and our own experience. This way, learning is individual for each learner. The child adapts its patterns of understanding by reflecting on previous theories or eliminating misconceptions.

It is therefore important to have a knowledge base for constructivist approaches to be effective. Brunner's spiral curriculum as an example of constructivism in action (Stevens-Fulbrook, 2019; Major theories and models of learning, 2020).

\section{Research Methodology}

In the study of the phenomenon of conscious fatherhood we proceed from the value and semantic orientation of upbringing. The methodological basis is chosen for the construction of a holistic modern system of education and its implementation in practice through the principles of systematic and integrated approach to education, synergy, continuity of generations, dialectic subjectobject relations of the educator and students and their parents, existentialpersonal communication, socio-cultural identity, nature-identity and ethnic basis. This makes it possible to practically form the new formations necessary for human existence. Such value orientations contribute to the integrity of upbringing, which over time will be transformed into self-education.

A comprehensive approach in the study of the phenomenon of conscious fatherhood involved the consideration of a group of phenomena as a whole; the unity of goals, objectives, content, methods and forms of interaction between teachers, the general public and the parents of students. An urgent need for such an approach arose due to the fact that the upbringing process in recent decades is actually seen as a sum of separate structural components. In addition, the 
formation of individual qualities - competences, rather than a holistic personality, is noted; the assessment of the educational impact of the whole population, including parents, the inclusion of the educational impact in social practice, the constant testing of educational efforts and their effectiveness.

\section{Results and Discussion}

In the formation of the idea of conscious fatherhood in the unity of Ukraine and Finland in the upbringing of the younger generation there were common blocks of ideas: increasing the level of morality in society because of the increase in the number of educated and spiritually developed people; harmonising moral and mental education, developing children's emotional intelligence, will and responsibility; creating a child-friendly environment in the immediate surroundings for upbringing.

We conducted a survey among parents of pre-school children in Kharkiv and the Kharkiv region and among parents of Finnish children (Table 1) The survey was conducted anonymously using social media, with the assistance of the Department of Science and Education of the Kharkiv Regional State Administration.

The aim of the survey was to find out the level of parents' interest in parenting and the holistic development of the child's personality and to collect empirical material on common forms of cooperation between teachers and parents of children. A similar survey was conducted among parents in Finland.

Table 1 Results of a Survey of Parents of Preschool Children in Ukraine (Kharkiv, Kharkiv region) and Finland

\begin{tabular}{|c|c|c|c|}
\hline Question & Response option & $\begin{array}{l}\text { Result } \\
\text { (Ukr) }\end{array}$ & $\begin{array}{l}\text { Result } \\
\text { (Fin) }\end{array}$ \\
\hline \multirow{3}{*}{$\begin{array}{l}\text { 1.Where do you get information on } \\
\text { parenting, your child's development? }\end{array}$} & From the internet & 42,3 & 60 \\
\hline & $\begin{array}{l}\text { Attending seminars, lectures for parents } \\
\text { (for fee) }\end{array}$ & 2 & 7,5 \\
\hline & $\begin{array}{l}\text { Getting information from an } \\
\text { educational instinstitution. }\end{array}$ & 55,7 & 32,5 \\
\hline \multirow{3}{*}{$\begin{array}{l}\text { 2. Do pre-schools provide parent } \\
\text { education and development } \\
\text { measures? }\end{array}$} & Yes & 79,1 & 62,5 \\
\hline & No & 6,2 & 2,5 \\
\hline & Not enough & 14,7 & 35 \\
\hline \multirow{2}{*}{$\begin{array}{l}\text { 3. Do pre-school educational } \\
\text { institutions carry out measures for } \\
\text { the upbringing and development of } \\
\text { children for parents? }\end{array}$} & Yes & 69,2 & 42,5 \\
\hline & No & 30,8 & 57,5 \\
\hline \multirow{3}{*}{$\begin{array}{l}4 \text { What information does the pre- } \\
\text { school provide on your child's } \\
\text { development? }\end{array}$} & The psychological state of the child & 24,7 & 45 \\
\hline & Development (ability) to succeed & 48,8 & 82,5 \\
\hline & $\begin{array}{l}\text { Make recommendations for the child's } \\
\text { further development and upbringing }\end{array}$ & 60,1 & 50 \\
\hline
\end{tabular}


SOCIETY. INTEGRATION. EDUCATION

Proceedings of the International Scientific Conference. Volume II, May $28^{\text {th }}-29^{\text {th }}$, 2021. 805-816

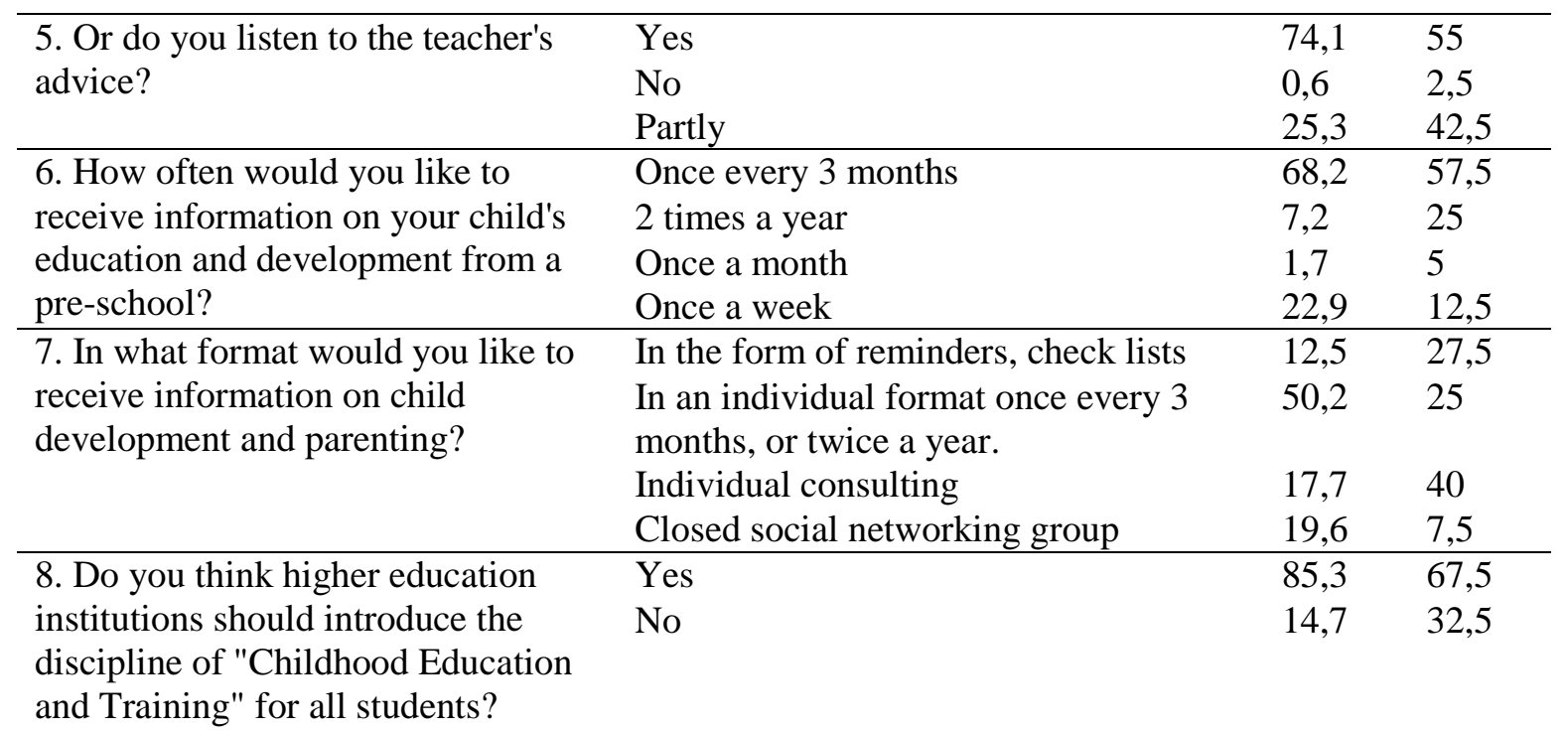

The results indicate the relevance of obtaining systematised information about education from educators at different levels of education. Discussions have arisen about the teaching of the course "Child rearing and education" for students of all specialisations. We have received proposals to introduce this course in high schools, vocational and pre-professional education institutions. After all, where there are subjects from media culture, digital literacy, sex education, and consciously choosing a profession, the issue of shaping vital competencies is successfully addressed.

It should be noted that educational institutions in Kharkiv and the Kharkiv region provide professional guidance, advice on children's development and upbringing for parents. Parents take an active part in various activities. So, for example, in the institution of pre-school education №416 of Kharkov. Kharkiv involves parents in cooperation in various activities, such as making thematic posters, entertainment, musical performances (Doshkilnyi navchalnyi zaklad (iasla-sadok) №416 Kharkivskoi miskoi rady, 2014). Active educational work is carried out by representatives of the parents' committee of preschool education institution №275 (Zaklad doshkilnoi osvity №275, 2014) Parents are maximally involved in the process of education and development of children, which means trust and respect for the teacher by parents and this is evidenced by the results of the survey (Table 1).

While in Ukraine, work with parents aims at harmonising the educational impacts of the institution and the family, in Finland the focus is on learning about the natural characteristics of individual children (Karkhurykhman and Karkhumyaki kindergarten, 2018). Finnish kindergartens involve parents in the discussion, namely through various activities for children, parents, teachers, and the direction to create a modern space for children that meets the needs and demands of the 21st century (Khattula Preschool Plan, 2019). They pose a 
question for all participants in the educational process: "How do you see the everyday life of a child in kindergarten?", "How does the change in status and teaching staff affect children and parents?", "What is important for children in kindergarten?" and more (Pelastakaa lapset, 2019).

It should be noted that in today's digital society, it is a good idea to listen to the opinions and wishes of children, to discuss with parents and teachers and to find a solution which is suitable for this group, kindergarten, taking into account the interests of all participants in the educational process. So there is no universal advice, but the issues that need to be raised and solutions sought are the modern recipe for the success and development of society. After all, given multiculturalism, which is present almost everywhere in the world and requires soft integration without compromising cultural self-identification.

The analysis of the answers made it possible to summarise that educational institutions carry out a sufficient number of parenting and parental education activities both in the city. Kharkiv and the Kharkiv region as well as in Finland. There is great interest and demand from parents for the introduction of discipline in youth education institutions at the Department of Pedagogy at Kharkiv National Pedagogical University named after G.S.Skovoroda. (Kafedra pedahohiky Kharkivskoho natsionalnoho pedahohichnoho universyteti imeni G.S.Skovorody) programme "Teacher Training to Work with Parents" Kyiv B.Grinchenko (Prezentatsiia tvorchykh robit z kursu "Pedahohika simeinoho vykhovannia" studentamy spetsialnosti "Sotsialna pedahohika", 2017).

Turning specifically to the history of the development of Ukrainian culture, numerous explanations of the essence and role of the mother and father, the nature and rights of the child in the pedagogical monuments of Ukrainian literature seem interesting. An a priori understanding of the role of personal example of parents in a child's life: in family relations, in relation to the history of the people, native nature, speech, behaviour, work and everyday life, learning and social and cultural growth, the desire and ability to bring up children, guided by the values of humanity and civil conscience, conscience and honour.

The above-mentioned ideas are vivid and relevant even for us, modern people, in the Book of Velesa, a folk folklore. The Ukrainian folklore expresses the opinion that one masters knowledge and experience through hard work: "Nobody was born wise", "Nobody was born a scientist", "Wise people are not born, but wise ones are made", "You study not until you are old, but until you die" (Ukrainski narodni pryslivia ta prykazky, 1984).

Pedagogical retrospection and expedient updating would require the work of I.Chrysostom (Ilin, 1997). He was convinced that to educate a child in charity is a matter of intelligence and great will. Successful upbringing and material prosperity ensure a good upbringing aimed at forming good behaviour and 
morals. I.Chrysostom regarded the frivolity of parents in bringing up their children as a common evil, a dishonour (Ilin, 1997).

The Ukrainian in the world is positioned with the Cossacks. In the study of the phenomenon of conscious fatherhood, the Cossack era has also had interesting developments. The objectives of Cossack education were formulated as follows: laying the solid foundations of the Orthodox faith, physical conditioning of the future warrior; development of an irreconcilable attitude to vice in any of its manifestations; cultivation of mental love of God and of others; the formation of a readiness for self-sacrifice. The growth of a child in a Cossack family took place in stages. The first was the transmission of religious and folk traditions, norms of behaviour from generation to generation in the family circle. As you know, the Cossacks had a great respect for a womanmother, who gave birth to a child and kept her alive for the first year. Historically in the Ukrainian culture there was a tradition that after the first year of life a child would be taken care of by its father. In the Cossack folklore the father symbolizes an unshakable authority in the relations with people, a model of courage and bravery. The young Cossack, entering the mature period of his life, always felt his father next to him as a symbol of ancestors (Yavornytskyi, 1990).

The upbringing of the future Cossack began at birth. The child was baptised on the eighth day of its life, and was given a name in accordance with the Holy Scriptures only. As soon as the baby's first teeth appeared, he was taken on horseback to the church to pray to St. John the Warrior so that he could grow up to be brave and faithful to the Orthodox Church. There was such a tradition at the Sich: children, who were either thrown under the gates of churches and other public buildings or were kidnapped in campaigns from foreign families in order to be converted into the Orthodox faith, as well as those who were abandoned by their single mothers, thus hiding their shame, who were orphaned, lost, etc. - Cossack brothers were subjected to their parental care (Drahomanov, 1876).

G.Skovoroda (2006) is a descendant of a famous family of Cossacks. The philosopher revealed his understanding of humanity in the phenomenon of conscious fatherhood in his pedagogical concept, in which he defined the heart as the basis of human growth. In the Enlightener's opinion, the sense and aim of educational influences was to cultivate the young man's gratitude to his parents, nature, and people. A person capable of being grateful even to enemies and opponents can achieve peace of mind, the so-called "hearty cheerfulness" (Skovoroda, 2006).

A. Makarenko (1973) held a similar position on the establishment of conscious parenthood as a value orientation. The pedagogue emphasized the exclusive role of true parental authority of demanding love to the child which is 
provided by one's own upbringing. An important aspect of manifestation of conscious fatherhood according to A. Makarenko is joint productive work of the child and his parents for the common good of the family, the child's feasible participation in all affairs of the family: patriotism, honesty, diligence, decent behavior in the family and outside it (Makarenko, 1973). This is in line with the Adlerian concept (Adler, 1997), which is based on the social character and the recognition and respect of the unity of family members. Accordingly, parenting involves changing the behaviour of all family members. The emphasis in parenting is on creating a certain atmosphere in the family. Children learn the value imperatives of "equality", "cooperation" and "natural results" for their parents (Adler, 1997). Interestingly, among the means of parenting in the Adlerian concept, the priority is to avoid power struggles in the family and to take into account the needs of the child. Parenting aims to help each parent to understand their child, to enter into his or her way of thinking and to learn to understand the motives behind his or her behaviour.

Family values, according to V. Sukhomlynskyi (1977), are the result of a vital selection of spiritual and moral laws of family existence and demonstrate an attitude towards the environment. It is known that parents cannot direct the child's life and activities fully, they can only pass on the moral guidelines that will determine the child's life activities in growing up. Family education contributes to the formation of the child through passing on the experience of previous generations, developing the habit of honouring ancestors, mutual support and assistance. In this way, the value of family unity, and therefore of the community and the nation as a whole, is formed. One cannot ignore the fact that under the influence of family value orientations, other spiritual values are selected at the personal level of the child. Sukhomlinsky rightly noted that when public spiritual values and ideals contradict personal ones developed under the influence of the family, part of the child's value system is rejected or destroyed, leading to a spiritual crisis that manifests itself primarily in disorientation and moral devastation. Such examples are, unfortunately, frequent in present Ukrainian society. This confirms the importance of creative use of the pedagogical heritage of the famous enlightener (Sukhomlynskyi, 1977).

We consider the considerations of Urszula Kazubowska (2019), who explored the importance of values in the context of identity formation, to be evidence of the systematic nature of such a position.

The conclusions of Marja Leena Böök \& Johanna Mykkänen (Böök, Mykkänen, 2019) are similar to our reasoning. In this vein, it is interesting that Finnish parents adhere to such conditions of child rearing. They try to guide their children rather than control them. To love as they are. To give them the right to choose. Let them take responsibility for their own learning, etc. Father and mother share responsibilities equally. Parents respect their children, their 
choices and their interests. They value individuality. Relationships are built on an equal level, male to female and parent to child. Problems are solved in the form of a dialogue in which the child is left with his or her own ideas, decisions and views. Parents share and respect the child's choices, take part in their interests and activities, and guide them, without reproach or punishment. Every child has a different pace of development, they learn from their mistakes, fall and rise. They look for themselves. In the meantime, parents watch and support their child with unselfish love. In the end, the child becomes what she should be. The idea of developing moral feelings, willpower and responsibility is systematic in the educational process with the support of conscious parenthood. We defined the basis of conscious fatherhood in Ukraine as moral experiences and the procedural actions of creating a moral, spiritually enriched experience that is realized in an act. Scientifically valuable is defined as the statement that feelings more fully reveal the true motives of man than his thinking. Therefore the practical part of the study focuses on creating methodologically valuable cognitive content for parents of 5-6 year old children. The content of this content should be modeled after informational messages (Volkova, VorozhbitHorbatiuk, 2020).

Pre-school education institutions in Ukraine are constantly updating information for parents on their official web pages. Parents receive advice from teachers, practicing psychologists and doctors. Various activities in which preschool children take part are highlighted (Doshkilnyi navchalnyi zaklad (iasla-sadok) № 353 Kharkivskoi miskoi rady, 2012).

An analytical comparison provides an opportunity to concretize the valuable findings of Ukrainian and Finnish educators. For example, Ben Furman (Furman, 2019) is known in Finland for his author's informative psychological programme, the implementation of which includes the development of procedural moments of mentoring, methodological support of education, team building, education and upbringing of children. actualization of considerations on historical and pedagogical sources. We have identified some overlap in the pedagogical heritage of K. Ushinskiy (1990), who developed pedagogical psychology based on the ideas of anthropology. A common form of schoolfamily cooperation initiated by K. Ushinskiy (1990) was school reports, the purpose of which was to inform parents about the children's behaviour, attentiveness and performance in learning, developmental characteristics of interests and tastes. And today's parents have the opportunity to find out everything they are interested in about their child at school, and doing homework will supplement their understanding of school activities.

The pedagogical considerations and conclusions of Finnish educators are in line with the recommendations of G. Skovoroda (2006) on kinship work, the value of the developmental resource of industrial work according to 
A. Makarenko (1973), the priority of empirical research in the field of educational psychology and pedagogy according to V.Sukhomlynskyi (1977). In the theory and practice of parent education in Finland, a programme of pedagogical education for parents has been developed and methodologically supported: social guides, encyclopaedic publications, popularising the values of family life among young people, for example the books Arja Sääkslahti "Liikunta varhaiskasvatuksessa", Eliisa Leskisenoja "Positiivisen pedagogiikan tyokalupakki" (Leskisenoja, 2017).

Active dialogue communication is also relevant today: parents talking about their children's lives, doing good deeds incognito, talking and leading by example. It is worth noting that the choice of educational influences, assistance in creating a close social environment - people and activities for the child (play, work), and personal examples are still in demand today. The concept of sensory communication also has a place in parenting programmes in Finland, in our opinion. A manifestation of this concept is the practice of organising parenting through so-called client-centred therapy sessions (creating conditions for selfexpression, shaping positive experiences of fatherhood). Among Finnish parents, the value proposition of this concept is that it is important to develop the competence of successful fathering - active listening, expressing feelings in a way that is accessible and understandable to the child; relying on the principle of "both sides can be right" in family interactions.

\section{Conclusions}

Analytical comparisons provide an opportunity to concretise the valuable practices of Ukrainian and Finnish educators. Open virtual space allows for a variety of social networking cells, but it should be noted that Ukrainian institutions have more open information about contemporary activities than Finnish ones. Ukrainian teachers are open to cooperation and exchange of experiences, but unfortunately Finnish teachers are more closed. Considering modern information technology, speech is no longer a barrier to communication. We Ukrainian scientists and educators would like more frankness from foreign countries' pedagogical systems with pre-school and school education.

To summarise the above, let us note. Parenting is a broad concept that essentially involves meeting the parents' need for pedagogical support, the child's need for educated parents, and the formation of social competences.

Valuable, in our opinion, is the desire of Ukrainian and Finnish pedagogues to preserve the nature of childhood: nothing can be demanded of a child's age other than that which is peculiar to children. It is rash to demand from a child constancy, and firmness, which are the result of experience, physical and spiritual maturity of an adult. Children should be given the opportunity to be 
children, help them to be good children, and good adults they will become later. Upbringing should always be tailored to the personality traits and obvious natural abilities of the pupils.

Among the prospects for further development of the topic, we see the search for constructive ways of open interaction between teachers, parents and children - pupils of Ukrainian and Finnish educational institutions of different levels.

\section{References}

Adler, A. (1997). Individual'naja psihologija kak put' $k$ poznaniju $i$ samopoznaniju cheloveka. Kiev: Nauka zhit', 1997. - 357s.

Böök, M.L., \& Mykkänen, J. (2019). Finnish Mothers' and Fathers'Constructions of and Emotions in Their Daily Lives. Scandinavian Journal of Educational Research, 63 (3), 412-426. doi: 10.1080/00313831.2017.1376351

Doshkilnyi navchalnyi zaklad. (2012). Doshkilnyi navchalnyi zaklad (iasla-sadok) № 353 Kharkivskoi miskoi rady. Retrieved from https://dnz353.klasna.com/uk/site/batkivskastorinka-1.html

Doshkilnyi navchalnyi zaklad. (2014). Doshkilnyi navchalnyi zaklad (iasla-sadok) № 416 Kharkivskoi miskoi rady. Retrieved from http://dnz416.edu.kh.ua

Drahomanov, M. (1876). Pro ukrainskykh kozakiv, tatar ta turkiv. Kyiv: B. v. 69 s.

Furman, B. (2019). Kids' Skills in Action. A playful and solution-focused approach to solving children's problems. AПkids. $235 \mathrm{~s}$.

Ilin, I.A. (1997). O vospitanii v gryaduschey Rossii. Sobranie sochineniy : V 10 t. Moskva: Russkaya kniga. T. 6. $560 \mathrm{s.}$

Kafedra pedahohiky Kharkivskoho natsionalnoho pedahohichnoho universyteti imeni G.S. Skovorody. (2019). Retrieved from: https://www.kaf-pedagogy-hnpu.com

Karkhurykhman and Karkhumyaki kindergarten. (2018). Retrieved from https://www.karhuryhma.fi/peruspilarit

Kazubowska, U. (2019). Values in the family - the specificity and transfer in the process of forming the identity of the child. SOCIETY. INTEGRATION. EDUCATION Proceedings of the International Scientific Conference, Volume III, May 24th -25th, 2019, Latvia, 240-253.

Keler, V. (1998). Geshtalt- psihologiya. Moskva: OOO "Izdatelstvo AST-LTD". 189 s.

Khattula Preschool Plan. (2019). Retrieved from https:/www.hattula.fi/wpcontent/uploads/2019/08/Kunta-Vasu-1.pdf

Leskisenoja, E. (2017). Positiivinen pedagogiikka varhaiskasvatuksessa - Toteuta käytännössä Rovaniemellä.

Lokk, Dzh. (2020). Myisli o vospitanii. Moskva. Retrieved from: http://jorigami.ru/PP_corner/Classics/Locke/Locke_John_Thought_concerning_educati on.htm (in Russian)

Major theories and models of learning. (2020). Lumen Educational Psychology. Retrieved from https://courses.lumenlearning.com/educationalpsychology/chapter/major-theoriesand-models-of-learning/

Makarenko, A. S. (1973). Knyha pro batkiv. Lektsii pro vykhovannia. Kyiv: Radianska shkola. $340 \mathrm{~s}$. 
Pavlov, I.P. (1954). Izbrannyie trudyi. Moskva: Uchpedgiz. 415 s.

Pelastakaa Lapset. (2019). (Save the Children). Myönteisesti Tunnistava Varhaiskasvatus Pilotti. Retrieved from: https://www.pelastakaalapset.fi/lapsilta-opittua/haluatkokehittaa-yhdessa-lasten-kanssa/myonteisesti-tunnistava-varhaiskasvatus-pilotti/

Pestalotstsy, Y. (2009). Knyha dlia materei. Retrieved from: https://bookz.ru/authors/ioganngenrih-pestalocci/kniga-dl_571.html

Piazhe, Z. (2008). Rech i myishlenie rebenka. Moskva: Direkt-Media.

Prezentatsiia tvorchykh robit. (2017). Z kursu "Pedahohika simeinoho vykhovannia" studentamy spetsialnosti "Sotsialna pedahohika". Retrieved from: https://il.kubg.edu.ua/struktura/kafedry-instytutu/kafedra-sotsialnoi-pedahohiky-tasotsialnoi-roboty/podii/1512-prezentatsiia-tvorchykh-robit-z-kursu-pedahohikasimeinoho-vykhovannia-studentamy-spetsialnosti-sotsialna-pedahohika.html

Skovoroda, H. S. (2006). Svit lovyv mene, ta ne vpiimav. Kharkiv: Folio. 607 s.

Stevens-Fulbrook, P. (2019). 15 Learning Theories in Education (A Complete Summary). Retrieved from https://teacherofsci.com/learning-theories-in-education/

Sukhomlynskyi, V. (1977). Pavlyska serednia shkola; Rozmova z molodym dyrektorom. Vybrani tvory: $v 5$ t., Kyiv: Radianska shkola. T. 4.638 s.

Ukrainski narodni pryslivia ta prykazky. (1984). Kyiv: Veselka. 64 s.

Ushinskiy, K.D. (1990). Chelovek kak predmet vospitaniya: Opyit pedagogicheskoy antropologii. Moskva, T. 5, 6.

Vashchenko, H. (1994). Vykhovnyi ideal. Poltava: Poltavskyi visnyk. 191s.

Volkova, Ya., \& Vorozhbit-Horbatiuk, V.V. (2020). Tsinnist interesiv dytyny yak bazys vzaiemodii batkiv dytyny i pedahohiv. The XXII th International scientific and political conference, Helsinki, Finland, 142-144.

Yavornytskyi, D.I. (1990). Istoriia zaporozkykh kozakiv. Kyiv: Osvita. T. 1. s. 236-238.

Zaklad doshkilnoi osvity. (2014). № 275. Retrieved from http://dnz275.edu.kh.ua 